\title{
Restoring and preserving capacity of self-affirmation for well-being in Indian adults with non-clinical depressive tendencies
}

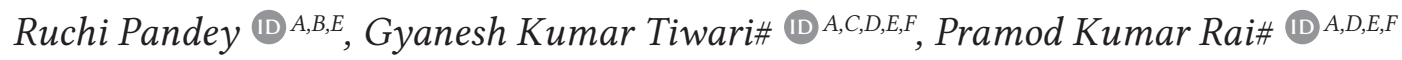 \\ \#Joint senior author. \\ Department of Psychology, School of Humanities and Social Sciences, Dr. Harisingh Gour University, Sagar, \\ Madhya Pradesh, India
}

\section{BACKGROUND}

Although self-affirmation has been reported to enhance well-being and other positive life outcomes in normal adults, little is known about its capacity to restore and preserve well-being in adults with depressive tendencies. The current study attempts to expound the restoring and preserving capacity of self-affirmation for well-being in Indian adults with non-clinical depressive tendencies.

\section{PARTICIPANTS AND PROCEDURE}

The study used a sequential research design. Eighty participants (22-27 years) with depressive tendencies were chosen through purposive sampling and were randomly assigned equally to the experimental and control conditions. Their depressive tendencies and well-being were measured through standard scales at three intervals: preintervention, post-intervention and follow-up.

\section{RESULTS}

The results revealed significant restoring and preserving capacity of self-affirmation for the well-being of the experimental group participants as compared to the control group. The main effects of conditions (experimental, control) and treatment intervals (pre, post, follow-up) were significant along with the interaction effects of conditions $x$ treatment intervals. The significant differences in the mean well-being scores for pre-intervention, post-intervention and follow-up points of time showed the restoring and preserving capacity of self-affirmation intervention.

\section{CONCLUSIONS}

The findings showed that self-affirmation helps to restore well-being as well as preserve it after a significant gap, which is evident in higher well-being mean scores of the experimental group taken at post-intervention and followup intervals. The positive effects of self-affirmation on well-being may have remained active even after the cessation of the intervention due to the underlying mechanisms of enhanced self-worth, positive values, inner strengths, positive attributions and interpersonal relationships.

\section{KEY WORDS}

non-clinical depressive tendencies; Indian adults; self-affirmation intervention; sequential research design; well-being

CORResPonding AUthor - Gyanesh Kumar Tiwari, Ph.D., Department of Psychology, School of Humanities and Social

Sciences, Dr. Harisingh Gour University, Sagar 470003, Madhya Pradesh, India, e-mail: gkt@dhsgsu.edu.in AUthors' CONTRIBUtion - A: Study design - B: Data collection - C: Statistical analysis - D: Data interpretation

E: Manuscript preparation - F: Literature search · G: Funds collection

to Cite this ARTICLE - Pandey, R., Tiwari, G. K., \& Rai, P. K. (2021). Restoring and preserving capacity of self-affirmation

for well-being in Indian adults with non-clinical depressive tendencies. Current Issues in Personality Psychology, 9(2), 135-147. 


\section{BACKGROUND}

A variety of life challenges related to health, relationships, performance and achievement may pose threats to the self-integrity and self-worth of people, which, in turn, may significantly shape their wellbeing and other life outcomes. In general, individuals use three methods to protect their self-integrity in the face of perceived threats. One method is to respond directly to the threatening situation by accepting the failures (Taylor \& Brown, 1988). The second way is to devaluate threat by using defence mechanisms (Sherman \& Cohen, 2002). Lastly, according to the self-affirmation theory, individuals may respond to threats indirectly by affirming their most preferred values, activities or attributes which provide them with more flexibility and enhanced availability of useful self-resources to deal with them (Steele, 1988; Steele et al., 1993).

According to Steele (1988), self-affirmation is a fundamental human motivation that entails an inborn drive for self-integrity, portraying individuals as good, virtuous, efficacious and able to predict and control their important life outcomes. Steele (1988) argued that individuals affirm their self-adequacy through available self-resources valuable to them which act as a buffer against the threatening situations (Steele et al., 1993). Thus, self-affirmation refers to the process of reflecting upon cherished values or attributes. Self-affirmation has been reported to help people to face internal and external threats and to promote health outcomes (Epton et al., 2015; Sweeney \& Moyer, 2015), resilience (Pandey et al., 2020b), self-worth (Critcher \& Dunning, 2015), self-control (Schmeichel \& Vohs, 2009), self-efficacy (Epton \& Harris, 2008), intrinsic aspirations (Schimel et al., 2004), pro-sociality (Burd \& Burrow, 2017) and behavioural engagement (Epton et al., 2015; Sweeney \& Moyer, 2015) on one hand and to reduce stress (Cook et al., 2012) and defensiveness (Schmeichel $\&$ Martens, 2005) on the other.

The benefits of self-affirming one's most preferred values, activities and attributes have been examined to influence both hedonic and eudaimonic well-being. The former reflects a higher frequency of positive emotions and reduced frequency of negative emotions while the latter entails fulfilment of psychological needs, the experience of meaning and purpose in life, and engagement in flow experiences (Ryan \& Deci, 2001). Nelson et al. (2014) examined the impact of a self-affirmation intervention of 2-week duration on hedonic and eudaimonic well-being of healthy participants in either a self-affirmation condition or a control condition. The study found that self-affirmation (a writing activity on a self-chosen value) condition participants exhibited enhanced well-being as compared to those who were assigned to a non-affirmed condition (a writing activity about a previous day) (Nel- son et al., 2014). Similarly, Armitage (2016) observed a positive impact of self-affirmation intervention on the well-being of women over 45 years old. This study observed that self-affirmation improved self-reported life satisfaction, well-being, and interpersonal feelings of kindness, love and joy (Armitage, 2016).

Self-affirmation has widely been manipulated by identifying the most preferred value and writing about its importance (McQueen \& Klein, 2006). Recent research has recommended the purpose in life method to induce self-affirmation due to its certain advantage over the value preference method (Burd $\&$ Burrow, 2017). Purpose in life is a dispositional resource which carries the advantage in facing threat similar to self-affirmation. Purpose in life denotes fundamental self-organizing life force which facilitates goals and regulates behaviours and a sense of meaning by directing the use of self-resources on one hand (McKnight \& Kashdan, 2009) and manages motivations and pursuits of life on the other (Martela \& Steger, 2016). It denotes an inclination to derive meaning from experiences and reflects intentionality and goal-directedness towards personally valued life outcomes (Ryff, 1989; Schaefer et al., 2013). Purpose in life may involve both internal and external orientations with the desire to make a difference in the social sphere (Damon et al., 2003). It is these attributes that make it a foundational psychological asset (Frankl \& Vance, 2005) and a basic constituent of psychological well-being (Ryff \& Keyes, 1995). On the other hand, self-affirmation refers to the process which helps individuals to cope with life threats by affirming some positive attributes of self (Cohen \& Sherman, 2014). Self-affirmation is simply the task through which individuals are reminded of their selfesteem and other self-resources. Self-affirmation has generally been induced by identifying the most preferred value and the participants are then instructed to write about its importance (McQueen \& Klein, 2006). But this method of manipulation is beneficial to those who possess high self-esteem and not to those who possess low self-esteem as in the case of persons with depressive tendencies. Thus, self-affirmation intervention is effective only for individuals who carry dispositional self-resources (Burd \& Burrow, 2017; Spencer et al., 1993).

Research reports that purpose in life and self-affirmation manipulation procedures have some commonality as well as differences. For example, both purpose and self-affirmation manipulation methods involve a writing task but their question stems vary (Burd \& Burrow, 2017). Whereas purpose manipulation is open-ended and does not prompt the participants to write about any specific value (Burrow \& Hill, 2013), most self-affirmation inductions direct them to write about the most preferred value (McQueen \& Klein, 2006). However, both methods capture expansive topics for writing, and thus manipu- 
lation of purpose in life is similar in procedure and theme to writing about the most important value by participants (Burd \& Burrow, 2017).

Studies have reported gender differences in stereotype threats (Miyake et al., 2010), self-esteem (Bleidorn et al., 2016), value preferences and self-construal (Cross \& Madson, 1997). The gender gap in self-esteem and self-resources, close allies of self-affirmation, is more pronounced in Western countries as compared to Eastern countries according to a cross-cultural study of 48 nations (Bleidorn et al., 2016). Along with other factors, these differences are largely due to differences in cultural values of males and females. Thus, males and females may have dissimilar self-resources between and within cultures such as self-construal (Cross \& Madson, 1997) and self-esteem (Sprecher et al., 2013) in their disposal to deal with the threats of their life. Studies suggest that women have more interdependent self-construal which leads them to form close and friendly relationships, to become more empathetic and harmonious with others than men. On the other hand, men possess a more independent selfconstrual which leads them to seek more autonomy and emotional detachment. Men may prefer a wider social connection while women may confine their relationships to dyad relationships (Baumeister \& Sommer, 1997; Cross \& Madson, 1997). The sex differences in self-construal may be larger in people from groups with poor gender gap and Human Development Index values and higher religiosity (Smith et al., 2020). These differences in men and women may make significant differences in the availability of resources to deal with the current threats and also benefits from interventions.

A close perusal of the literature suggests the efficacious role of self-affirmation interventions on the positive life outcomes of normal individuals who were facing no significant threats to their self-integrity (Nelson et al., 2014) or facing some artificially created threats (Armitage, 2016). Although the efficacy of self-affirmation intervention has been examined through it impacts on the well-being of normal persons or persons facing perceived threats caused by social exclusion, prejudice and some imagined situations in previous studies, there is a dearth of studies that have observed the effectiveness of selfaffirmation intervention influencing the well-being of people possessing non-clinical depressive tendencies. Moreover, research on gender differences linked to the impacts of self-affirmation intervention on various life outcomes is also very limited. Previous studies have been confined to assessing the efficacy of self-affirmation on acute threats such as healthrisk messages (Inglehart, 2002), and thus there is little research on chronic threats such as depressive tendencies (Armitage, 2016). Understanding the restoring and preserving capacity of self-affirmation for the well-being of individuals facing psychopatholog- ical symptoms may have theoretical as well as practical implications. The current study attempts to fill this gap by exploring the efficacy of self-affirmation intervention on the well-being of Indian adults with non-clinical depressive tendencies.

\section{PARTICIPANTS AND PROCEDURE}

The present study employed a sequential research design which used a 2 (affirmed condition, non-affirmed condition $) \times 2$ (male, female) $\times 3$ (pre-intervention, post-intervention, follow-up) mixed factorial design repeated on the last factor.

\section{PARTICIPANTS}

Eighty participants were screened out of 504 undergraduate and postgraduate students pursuing different academic programmes at the various departments of Dr. Harisingh Gour University, Sagar, Madhya Pradesh, India. Out of the chosen sample, 27 were male (age range $=22-27$ years, $M=24.26$, $S D=1.51)$ and the rest 53 were female participants (age range $=22-27$ years, $M=24.53, S D=1.80$ ). They were chosen through a purposive sampling method and assigned randomly in equal numbers to the experimental and control conditions. They were the residents of different places of India and belonged mostly to the middle socioeconomic status.

A priori power analysis was performed for estimating sample size to assess the effects of conditions and gender on the well-being of the participants in pre, post and follow-up conditions. A large effect size of 0.40 was chosen as per the criteria suggested by Cohen $(1988,1992)$ with $\alpha=.05$ and power $=0.90$. The projected sample size required to achieve this effect size was $N=24$ for between and within comparisons. Power analysis was done with the help of $G^{*}$ Power 3 (Faul et al., 2007). We propose a sample size of 80 which will be sufficient to attain the study objectives (main and interaction effects).

\section{INCLUSION AND EXCLUSION CRITERIA}

The unmarried male and female participants who achieved above $75^{\text {th }}$ percentile scores on the Depressive Episodes and Depressive Tendencies Scale (Aarø et al., 2011), familiar with English and Hindi languages and pursuing undergraduate and postgraduate programmes at Dr. Harisingh Gour University, Sagar, Madhya Pradesh, India with no known physical and mental disease were included in the study. Those who scored below the $75^{\text {th }}$ percentile on the depressive tendencies measure, married, non-fluent in either English or Hindi languages, discontinued their 
studies and reported some sort of health problems were excluded from the study.

\section{MEASURES}

The following psychometric tools were used in the current study:

Mental Health Continuum-Short Form. The wellbeing of the participants was measured by the Mental Health Continuum-Short Form (Keyes, 2005). This measure of well-being lends its genesis from the theories of emotional well-being (Diener et al., 1999), hedonic and eudaimonic well-being (Ryff, 1989) and social well-being (Keyes, 1998). It comprises 14 items with a 6-point scale ranging from never to almost every day. The aggregate score on the scale represents the well-being of an individual. The higher the score on the measure, the higher was the well-being of the participants. The internal consistency reliability of the scale has been reported to be more than .80 (Keyes, 2005; Pandey et al., 2020a, 2021). The Cronbach's $\alpha$ for the scores of the participants of the present study on this measure was .91.

Depressive Episodes and Depressive Tendencies Scale. To assess the depressive tendencies of the participants, the Depressive Episodes and Depressive Tendencies Scale (Aarø et al., 2011), which contains 7 items with 'yes' or 'no' response alternatives, was used. The Cronbach's $\alpha$ of this measure was .78 (Aarø et al., 2011). Since this measure was developed on the non-Indian population, the researchers adapted it to the Indian population before using it. For this, the face validity of each item of the scale was established by three experts followed by a pilot study on 150 adults (age range $=20-30$ years) comprising 50 participants with depressive tendencies and 100 participants with non-depressive tendencies. The Cronbach's $\alpha$ coefficient of the measure for the current sample was .96. This scale is popular among researchers across the globe (Archer et al., 2013; Cassidy et al., 2018; Ugwu et al., 2015).

\section{PROCEDURE}

The study was approved by the Ethics Committee of Dr. Harisingh Gour University, Sagar, Madhya Pradesh, India. The notice of the study was posted on social media and those who showed interest in participating were contacted personally and briefed about the goals of the study. Before administering pre-intervention measures (the Depressive Episodes and Depressive Tendencies Scale tendencies and the Mental Health Continuum-Short Form), informed written consent was taken from each participant. Five hundred and four participants turned up and only those participants were chosen whose scores fell above the $75^{\text {th }}$ percentile on the Depressive Episodes and Depressive Tendencies Scale (Aarø et al., 2011) and also fulfilled other inclusion criteria. After obtaining pre-test scores on the depressive and wellbeing measures, half of the participants were randomly assigned to the experimental $(n=40)$ and half to the control $(n=40)$ conditions. Self-affirmation intervention was given to the experimental group whereas the control group participants wrote about mundane facts and experiences of their daily life for 15 days. The post-test scores on the two measures were taken on the last day of the intervention while the follow-up measure was taken after 10 days of the elapse of the post-test measure.

\section{SELF-AFFIRMATION INTERVENTION}

Research reports that the manipulations and induction of self-affirmation and purpose in life may partially overlap and both carry similar advantages in responses to threat (Burd \& Burrow, 2017). Purpose in life and self-affirmation are very similar in nature and can be used as a tool to induce self-affirmation in individuals (Burd \& Burrow, 2017). By reminding the individuals about their purpose in life, one unobtrusively affirms the self regarding their higher vision in life. Hence purpose in life and self-affirmative sentences are included as part of the self-affirmation intervention. Thus, based on this recommended similarity in procedure and theme and equal efficacy of purpose in life for persons with low and high self-esteem, the current study employed a blend of purpose in life and affirmation as the method for manipulating self-affirmation.

Self-affirmation represents a useful awareness of the self-resources of individuals. There were various issues regarding how, what and why about the self-affirmation intervention. Keeping duration as an important predictor of the success of an intervention (Cook et al., 2012; Lyubomirsky \& Layous, 2013) and modules popularly being used for happiness intervention in mind (McQueen \& Klein, 2006), the duration of intervention in the current study was set at 15 days and the follow-up measures were taken after a period of 10 days from the post-test measure. Contrary to the majority of the previous studies that used hypothetical threats and short self-affirmation intervention (McQueen \& Klein, 2006), the participants in the current study were facing real threats in the form of depressive tendencies and were provided with a longer intervention duration of 15 days.

In this study, the self-affirmation intervention for the participants of the experimental group comprised affirmative writings about the most preferred values (e.g., I am good at mathematics) and the writings of purpose in life (e.g., I have lots of reasons for living) (Scheier et al., 2006). Here, affirmation was not limited 
to a particular set of values. They were asked to write self-affirmative sentences twice a day (early in the morning and at night before going to bed) regularly for 15 days. They were also asked to write about their purpose in life every other day (e.g., $1^{\text {st }}$ day, $3^{\text {rd }}$ day, $5^{\text {th }}$ day and so on) during the day hours (around noon) for 15 days. The participants were briefed about the intervention and were provided prototypes of the writings so as to familiarize them with the tasks. They were also provided with the writing materials (a diary and a pen) to maintain a written record of all the intervention-related activities in their diaries, which were received back after the completion of the intervention. On the other hand, the control group participants were asked to write about the mundane facts of their daily life (i.e., I took breakfast and completed my studies today) regularly for 15 days. The duration of writing for both groups in each session was 10 minutes. An outline of the intervention plan is presented in Table 1 .

\section{STATISTICAL ANALYSES}

The descriptive statistics of mean and standard deviation (SD) were computed. Analysis of variance (ANOVA) was also computed to partial out the main and interaction effects of the conditions (experimental and control), gender (male and female) and treatment intervals (pre, post and follow-up) on wellbeing. The analysis was done using a bootstrapped sample of 1000 . This method has been suggested for data analysis which does not follow a normal distribution (Bishara \& Hittner, 2017; Wright et al., 2011).

\section{RESULTS}

The depressive tendencies scores of the participants during pre, post and follow-up intervals were assessed. The female participants of the experimental group showed a higher score on the depressive tendencies measure $(M=5.41, S D=0.57)$ as compared to their male counterparts $(M=4.91, S D=0.54)$ in pre-intervention while this trend was reversed in the post-intervention condition [male $(M=1.91$, $S D=0.83)$, female $(M=1.79, S D=0.94)]$ and remained stable in the follow-up [male $(M=2.09, S D=1.30)$, female $(M=2.07, S D=0.88)]$. For the control condition, males showed higher mean scores [pre-intervention $(M=5.94, S D=0.25)$, post-intervention $(M=5.25$, $S D=0.68)$, follow-up $(M=5.25, S D=0.68)]$ than the females [pre-intervention $(M=5.71, S D=0.55)$, post-intervention $(M=5.21, S D=0.72)$, follow-up $(M=5.21, S D=0.72)]$. The main effect of gender was computed using a 2 (experimental, control) $\times 2$ (male, female) $\times 3$ (pre, post, follow-up) mixed factorial $\operatorname{ANOVA}\left(F(1,76)=0.01, p=.944, \eta^{2}=0.00\right.$, power $\left.=.05\right)$ which revealed no gender differences in the depressive tendencies scores. Also the male and female participants did not differ significantly in their mean depressive scores in pre-intervention $(t(78)=0.20$, $N=80, p=.840, S E=0.14,95 \% \mathrm{CI}=-.31-.25$, $d=0.05$, power $=.06$ ).

Table 1

Summary of the intervention plan for the experimental and control group participants

\begin{tabular}{|c|c|c|c|c|c|c|c|c|}
\hline $\begin{array}{l}\text { S. } \\
\text { No. }\end{array}$ & Group & Task & Frequency & Time & Counts & Duration & $\begin{array}{l}\text { Writing } \\
\text { duration }\end{array}$ & Example \\
\hline \multirow[t]{2}{*}{1.} & $\begin{array}{l}\text { Experi- } \\
\text { mental } \\
\text { group }\end{array}$ & $\begin{array}{l}\text { Self-affirma- } \\
\text { tive writing }\end{array}$ & $\begin{array}{l}\text { Twice } \\
\text { a day }\end{array}$ & $\begin{array}{c}\text { In early } \\
\text { morning } \\
\text { and at night } \\
\text { (before going } \\
\text { to bed) }\end{array}$ & $15 \times 2=30$ & 15 days & $10 \mathrm{~min}$ & $\begin{array}{l}\text { I paint very } \\
\text { well. }\end{array}$ \\
\hline & & $\begin{array}{l}\text { Purpose } \\
\text { in life }\end{array}$ & $\begin{array}{c}\text { Every } \\
\text { other day }\end{array}$ & Around noon & $\begin{array}{c}1^{\text {st }}, 3^{\text {rd }} \\
5^{\text {th }}, 7^{\text {th }} \\
9^{\text {th }}, 11^{\text {th }} \\
13^{\text {th }} \& \\
15^{\text {th }}=8\end{array}$ & 15 days & $10 \mathrm{~min}$ & $\begin{array}{l}\text { Most of my life } \\
\text { efforts are } \\
\text { valuable, } \\
\text { meaningful and } \\
\text { goal-directed. }\end{array}$ \\
\hline 2. & $\begin{array}{l}\text { Control } \\
\text { group }\end{array}$ & $\begin{array}{l}\text { Writing of } \\
\text { mundane } \\
\text { life facts and } \\
\text { experiences }\end{array}$ & Daily & Around noon & 15 & 15 days & $10 \mathrm{~min}$ & $\begin{array}{l}\text { I have bought } \\
\text { vegetables } \\
\text { today/ I will } \\
\text { go outside for } \\
\text { dinner in the } \\
\text { evening. }\end{array}$ \\
\hline
\end{tabular}


Table 2

Mean well-being scores of the male and female participants in pre, post and follow-up measures for experimental and control conditions

\begin{tabular}{|c|c|c|c|c|c|}
\hline Treatments & Conditions & Gender & M & $S D$ & $n$ \\
\hline \multirow[t]{6}{*}{ Pre-intervention } & Experimental & Male & 27.46 & 4.66 & 11 \\
\hline & & Female & 31.86 & 12.20 & 29 \\
\hline & & Total & 30.65 & 10.79 & 40 \\
\hline & Control & Male & 33.38 & 5.89 & 16 \\
\hline & & Female & 31.58 & 10.13 & 24 \\
\hline & & Total & 32.30 & 8.64 & 40 \\
\hline \multirow[t]{6}{*}{ Post-intervention } & Experimental & Male & 55.55 & 9.64 & 11 \\
\hline & & Female & 56.90 & 7.12 & 29 \\
\hline & & Total & 56.53 & 7.79 & 40 \\
\hline & Control & Male & 32.69 & 5.50 & 16 \\
\hline & & Female & 31.13 & 8.97 & 24 \\
\hline & & Total & 31.75 & 7.72 & 40 \\
\hline \multirow[t]{6}{*}{ Follow-up } & Experimental & Male & 48.91 & 10.94 & 11 \\
\hline & & Female & 49.48 & 12.71 & 29 \\
\hline & & Total & 49.33 & 12.11 & 40 \\
\hline & Control & Male & 31.94 & 5.35 & 16 \\
\hline & & Female & 31.13 & 8.35 & 24 \\
\hline & & Total & 31.45 & 7.23 & 40 \\
\hline
\end{tabular}

The means and SDs of the scores of the wellbeing of the participants are presented in Table 2 . A summary of the ANOVA is presented in Table 3. Table 3 shows that the main effects of conditions (experimental and control) $(F(1,76)=66.92, p<.001$, $\eta^{2}=0.47$, power $\left.=.99\right)$ and treatment intervals (pre, post and follow-up) $(F(2,152)=49.73, p<.001$, $\eta^{2}=0.40$, power $\left.=.99\right)$ were statistically significant for the well-being measure. These findings showed that the self-affirmation intervention had significant restoring and preserving effects on the well-being of the participants with non-clinical depressive tendencies. Likewise, the interaction effect of conditions $\times$ treatment intervals was also statistically significant for the well-being measure $(F(2,152)=55.48, p<.001$, $\eta^{2}=0.42$, power $\left.=.99\right)$. The main effects of gender and other interactions were statistically non-significant (see Table 3).

To understand the effect size of self-affirmation intervention for the conditions and treatment intervals on the well-being of the participants, partial eta squared $\left(\eta^{2}\right)$ values were computed as per the suggestion of Cohen (1988). Cohen $(1988,1992)$ has recom- mended that the $\eta^{2}$ values of $0.10,0.25$ and 0.40 indicate low, medium and large effect size, respectively. The results showed that the conditions [experimental $(M=45.03, S E=1.18,95 \% \mathrm{CI}=42.68-47.37)$; control $(M=31.97, S E=1.08,95 \% \mathrm{CI}=29.83-34.11)]$ exerted a larger effect $\left(\eta^{2}=0.47\right)$ of self-affirmation intervention on the well-being of the participants with nonclinical depressive tendencies. The effect size of the main effect of the gender [male $(M=38.32, S E=1.30$, $95 \% \mathrm{CI}=35.72-40.92)$ and female $(M=38.68$, $S E=0.92,95 \% \mathrm{CI}=36.85-40.51)]$ shows a very low effect $\left(\eta^{2}=0.01\right)$ of self-affirmation intervention on the well-being of the participants with non-clinical depressive tendencies (see Table 3).

Likewise, the effect size of the main effect of the treatment intervals [pre $(M=31.07, S E=1.17,95 \%$ $\mathrm{CI}=28.74-3.40)$; post $(M=40.05, S E=0.94,95 \%$ $\mathrm{CI}=42.20-45.93)$ and follow-up $(M=40.36, S E=1.21$, $95 \% \mathrm{CI}=37.96-42.77)]$ shows a larger effect $\left(\eta^{2}=0.40\right)$ of self-affirmation intervention on the well-being of the participants with depressive tendencies. The interaction effects of the conditions $\times$ treatment intervals [experimental (pre $(M=29.66, S E=1.73,95 \%$ 
$\mathrm{CI}=26.21-33.11)$, post $(M=56.22, S E=1.39,95 \%$ $\mathrm{CI}=53.46-58.98)$, follow-up $(M=49.20, S E=1.79,95 \%$ $\mathrm{CI}=45.64-52.76)$ ); control (pre $(M=32.48, S E=1.58$, $95 \% \mathrm{CI}=29.34-35.62)$, post $(M=31.91, S E=1.26,95 \%$ $\mathrm{CI}=29.39-34.42)$, follow-up $(M=31.53, S E=1.63,95 \%$ $\mathrm{CI}=28.29-34.78))]$ also seem to exert a larger effect $\left(\eta^{2}=0.42\right)$ of the self-affirmation intervention on the well-being of the participants with depressive tendencies (see Table 3).

These findings have also been presented in Figure 1 and Figure 2. These figures represent a figural form of simple effects ANOVA (a form of post-hoc comparisons) which clearly shows the patterns of ef- fects of the self-affirmation intervention on the wellbeing of the male and female participants with the depressive tendencies shaped by the conditions (experimental and control) and treatment intervals (pre, post and follow-up).

\section{DISCUSSION}

The findings proved the contention that the self-affirmation intervention used in the present study helped to restore and preserve the lowered well-being due to the presence of higher depressive tendencies in

Table 3

Summary of ANOVA of $2 \times 2 \times 3$ factorial design repeated on the last factor for well-being

\begin{tabular}{|c|c|c|c|c|c|c|c|}
\hline Source of variance & SS & $d f$ & MS & $F$ & $p$ & $\eta^{2}$ & Power \\
\hline \multicolumn{8}{|l|}{ Between SS } \\
\hline Conditions & 8906.33 & 1 & 8906.33 & 66.92 & .001 & .47 & .99 \\
\hline Gender & 6.81 & 1 & 6.81 & 0.05 & .822 & .01 & .06 \\
\hline Conditions $\times$ Gender & 160.06 & 1 & 160.06 & 1.20 & .276 & .02 & .19 \\
\hline Error (between) & 10115.18 & 76 & 133.10 & & & & \\
\hline \multicolumn{8}{|l|}{ Within SS } \\
\hline Treatment intervals & 6248.56 & 2 & 3124.28 & 49.73 & .001 & .40 & .99 \\
\hline Conditions $\times$ Treatment intervals & 6971.19 & 2 & 3485.60 & 55.48 & .001 & .42 & .99 \\
\hline Gender $\times$ Treatment intervals & 23.44 & 2 & 11.72 & 0.19 & .830 & .01 & .08 \\
\hline $\begin{array}{l}\text { Conditions } \times \text { Gender } \times \text { Treatment } \\
\text { intervals }\end{array}$ & 52.70 & 2 & 26.35 & 0.42 & .658 & .01 & .12 \\
\hline Error (within) & 9549.77 & 152 & 62.83 & & & & \\
\hline Total & 42034.04 & 239 & & & & & \\
\hline
\end{tabular}

Note. SS - sum of squares, MS - mean squares.

\section{Figure 1}

Simple effects of conditions $(A)$ and gender (B) for pre (c1), post (c2) and follow-up (c3) measures for mean well-being scores

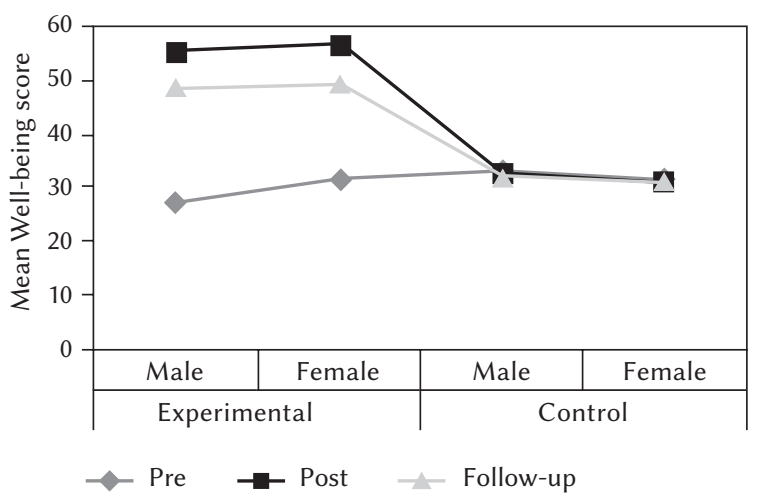

Figure 2

Simple effects of treatments $(C)$ and gender $(B)$ for experimental (a1) and control (a2) conditions for mean well-being scores

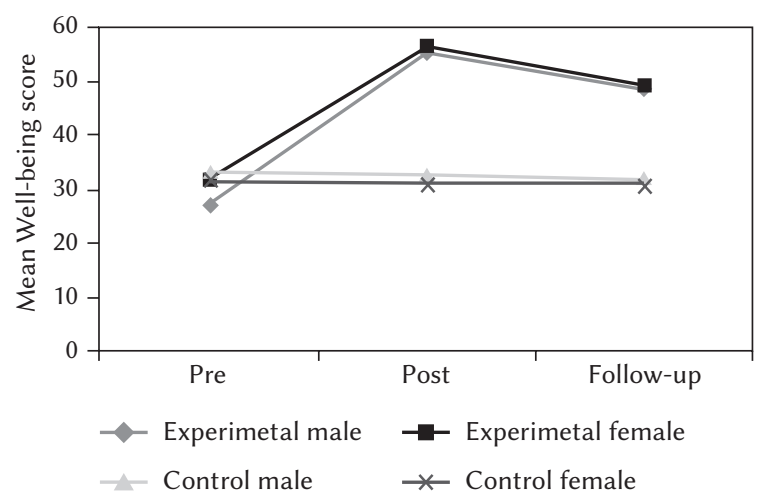


the participants. The main effects of conditions (experimental and control) and treatment intervals (pre, post and follow-up) were statistically significant along with the interaction effect of the conditions and the treatment intervals. The restoring power of self-affirmation intervention for well-being is explicitly evident in the obtained significant differences in its mean scores for the participants with depressive tendencies in pre- and post-intervention measures whereas the preserving strength is perceptible in the significant differences in the mean well-being scores in the post-intervention and follow-up intervals. The main effect of conditions (experimental and control) revealed that self-affirmation intervention was manipulated successfully and had a significant effect on the well-being of the participants.

Manipulation of self-affirmation through purpose in life has been successful, which is evident in the lower scores of the participants on the depressive tendencies measure and enhanced scores on the wellbeing measure. Similar to the findings of the current study, previous research has shown promotive capacity of purpose in life for psychological well-being (Ryff \& Keyes, 1995). Purpose in life may have shown restorative and preserving capacities due to its ability to induce coherence, purpose and significance in the life of the participants (Martela \& Steger, 2016). It may have enhanced the well-being of the participants of the experimental group as it has been suggested to reflect a sense of meaning by directing the use of self-resources (McKnight \& Kashdan, 2009), to control motivations (Martela \& Steger, 2016) and to ascertain goal-directedness (Schaefer et al., 2013). A good number of studies have reported the beneficial effects of purpose in life on health outcomes (Scheier et al., 2006) and general well-being and lifesatisfaction (Burrow \& Hill, 2011; Scheier et al., 2006; Sumner et al., 2015).

However, there is a slight downward trend in the well-being of the participants between the postintervention and the follow-up. The persistence of the negative life situations and experiences which had caused them to develop depressive tendencies earlier may be one reason. Social and psychological well-being involves aspects (e.g., social contribution, social acceptance, environmental mastery, positive relations with others and personal growth) which require a relatively long time to stabilize, and thus a decreasing trend in their well-being after cessation of the intervention may have occurred. Although there is a declining trend in their well-being between the post and the follow-up period, their well-being level is higher as compared to the pre-intervention. Some studies reflect upon the factors which wane over the positive effects of self-affirmation after a reasonable gap. For example, hedonic adaptation after elapse of intervention (Nelson et al., 2014), lack of personactivity fit (e.g., self-reflection), lack or absence of threat to self-integrity after self-affirmation (Schmeichel \& Vohs, 2009; Steele, 1988), weak nature of the threat (Howell, 2017), the familiarity of intended outcomes of intervention (Cohen \& Sherman, 2014), type of values (e.g., affirming materialistic or egocentric values) (Shnabel et al., 2013) and reduced quality of reasoning after affirmation (Munro \& Stansbury, 2009) may have caused a downward trend in their well-being.

Contrary to previous research which reported gender differences in self-esteem (Sprecher et al., 2013), self-construal (Bleidorn et al., 2016; Cross \& Madson, 1997), interpersonal relationship patterns (Smith et al., 2020) and other allies of self-affirmation and suggested gender difference in self-affirmation benefits, the findings of the current study show no gender differences in their well-being scores due to the intervention. This may be due to the fact that the participants in the current study are well-educated and perceive equal social and economic opportunities. The suggested precursor of gender differences in self-resources such as self-esteem, self-construal, interpersonal relationship patterns and gender stereotypes are changing at a fast pace due to government policies, changing attitudes of society, mass media and life opportunities, and thus men and women may have equal and sufficient resources to deal with their depressive tendencies and improve well-being. Mass media, family and government awareness programmes constantly provide positive feedback about the gender of women, which has been suggested to decrease gender stereotypes and improve positive life outcomes (Ogihara, 2020; Spencer-Rodgers et al., 2016).

Researchers have suggested a variety of mechanisms behind the positive roles of self-affirmation in shaping well-being and other desirable life outcomes. For example, Harris et al. (2019) have identified three basic mechanisms, namely, positive and useful values, personal intrapersonal strengths and constructive interpersonal and social relationships underlying self-affirmation. The researchers have argued that these sources of self-affirmation provide the flexibility to use the available self-resources on the part of individuals. Due to these attributes, selfaffirmation interventions show their efficacy in lowering rumination and negative thinking (Koole et al., 1999), thought suppression (Koole \& van Knippenberg, 2007), pain, tiredness, drowsiness, lack of appetite, anxiety, lack of well-being, suicidal ideation and suicidal behaviours (Russell et al., 2018; Yildirim et al., 2017).

Research suggests that self-affirmation may enhance well-being by initiating a cycle of adaptive potential through mutually rewarding interactions between the self-system and the social system which may endure long after the intervention has receded in time and memory (Walton \& Cohen, 2011). The adap- 
tive potential of self-affirmation is carried forward by recursion (perpetuating itself), interaction (a process can interact with other processes in the environment) and stable shift in perception (Cohen et al., 2012; Sherman, 2013). The cycle of adaptive potential may also facilitate the prophylactic effects of selfaffirmation intervention for well-being by changing the self-construal of the individuals (Harackiewicz et al., 2014). It may do so by forming realistic and concrete life goals and restored affirmation (Gollwitzer \& Sheeran, 2006; Schmeichel \& Vohs, 2009). Thus, it may buffer against the further occurrence of depressive tendencies and may promote well-being by helping individuals to use meaning-making affirmation (Keough \& Markus, 1998), to interrupt negative cycles (Logel \& Cohen, 2012), to reduce defensive behaviour in interpersonal situations and to uphold positive belief and closeness in relationships (Crocker et al., 2008). Well-being may also be improved and maintained by changing the narratives of relationships from negative to positive, which triggers adaptive potential (Cacioppo \& Patrick, 2009).

Research reports that self-affirmation relates closely to self-control (Schmeichel \& Vohs, 2009), self-efficacy (Epton \& Harris, 2008), intrinsic aspirations (Schimel et al., 2004), prosociality (Crocker et al., 2008; Thomaes et al., 2012), positive engagement and life success (Cooke et al., 2014), which are close allies of well-being (Howell, 2017). The positiveactivity model (Lyubomirsky \& Layous, 2013) posits that self-affirmation enhances intentional activities such as positive thoughts, positive emotions, positive behaviours and need satisfaction, which, in turn, may enhance well-being.

Similar to the findings of the current study, some earlier studies have suggested self-affirmation to be helpful and effective in enhancing happiness (Sin \& Lyubomirsky, 2009), kindness (Lyubomirsky et al., 2005), gratitude (Boehm et al., 2011) and optimism (Layous et al., 2013), which are precursors of wellbeing. Self-affirmation also enhances close allies of well-being such as self-esteem and interpersonal feelings (Armitage \& Rowe, 2011), objective information processing (Armitage, 2016) and motivation and behaviour change (Armitage et al., 2011) and reduces the tendency of individuals to process threatening information defensively, which, in turn, may have enhanced the well-being of the participants in the current study. The capacity of self-affirmation to bolster self-image (Steele, 1988) has been suggested to improve happiness and meaning (Nelson et al., 2014) which may be another reason to restore and preserve well-being. Nelson et al. (2014) have argued that self-affirmation also increases self-control, which, in turn, stretches self-resources consequently leading to improved well-being. Some recent studies have also shown the benefits of practising self-affirmation (Cheng et al., 2020; Hill et al., 2020; Howell, 2017).
Contrary to the previous study that suggested selfaffirming to be less effective in boosting well-being (Armitage, 2016), the current study showed that it may restore as well as preserve well-being over some time after the elapse of the intervention. This is the most notable contribution of the present study to the science of self-affirmation.

Self-affirmations may be effective in restoring and preserving the well-being of the participants with depressive tendencies since it portrays individuals as valued, loved, healthy, positive, productive, unique, meaningful, strong, self-aware, physically potent and resilient. Depressive tendencies are characterized by emotional, cognitive and physical disturbances that significantly challenge the self-integrity and reduce the availability of self-resources to deal with the threats of life of people. The self-affirmation intervention employed in the current study may have helped the participants to affirm and reactivate their sense of self-worth, integrity and positive strengths to significantly lower their feeling of worthlessness or excessive guilt, poor concentration, indecisiveness and recurrent negative thoughts (features of depressive tendencies) on one hand and restore and consolidate the well-being on the other.

Self-affirmation represents a useful awareness of the self-resources of individuals. The findings of the current study have shown that self-affirmation is an effective way to help individuals to restore their lowered well-being and maintain it. The present study represents one of the few studies which show that the lowered well-being due to the presence of depressive tendencies may be restored and preserved with the help of self-affirmation interventions. The restored self-worth and self-resources caused by self-affirmation may remain effective even after the cessation of self-affirmation intervention due to reverberating effects which make available needed positive selfresources on the part of the sufferers.

\section{IMPLICATIONS FOR THEORY, RESEARCH, PRACTICE AND POLICY}

The findings of the current study showed that selfaffirmation catalyses a set of intrapersonal resources which have promotive and strengthening roles for well-being. The findings demonstrated that self-affirmation interventions not only showed restoring capacity but also preserving capacity for the well-being challenged by a chronic threat such as depressive tendencies. The self-affirmation intervention method used in this study is easy, economical, and adaptable to the needs of individuals, communities and societies. There is much scope for future researchers to contribute to the field of self-affirmation. Future researchers can add significantly by using mixed methods or qualitative methods and assessing their 
effectiveness in diverse age and cultural groups, since people belonging to individualistic and collectivistic societies have different self-construal and priorities (Pandey et al., 2020a; Tiwari et al., 2020a, b).

There are some limitations to the current study. For example, the study recruited only a small number of participants with non-clinical depressive tendencies, and thus the conclusions of the current study may need precaution when generalizing to clinical populations. Moreover, there are cultural variations in the expressions of symptoms. For example, the Chinese report more somatic symptoms when facing depression than Nigerians (Kleinman, 1977). Since there are cultural differences in the expressions of the depressive and other psychopathological symptoms (Kleinman, 1977; Lin \& Cheung, 1999; Pandey, 2021; Zhu, 2018), future research may consider exploring the cultural peculiarities of values and expressions and design their self-affirmation interventions accordingly.

Thus, self-affirmation is affirming of individuals in their most preferred values, activities and attributes. It is a fundamental human motivation that supports self-integrity and portrays individuals as good, virtuous and efficacious. It facilitates a variety of positive life outcomes by catalysing a plethora of self-resources of healthy individuals with or without threats. Self-affirmation intervention has restoring and preserving capacity for well-being in adults with non-clinical depressive tendencies. The positive effects of self-affirmation on well-being may remain active even after the cessation of the intervention. Enhanced self-worth, positive values, inner strengths, positive attributions and interpersonal relationships may be some underlying mechanisms behind its positive effects.

\section{References}

Aarø, L. E., Herbeć, A., Bjørngaard, J. H., Mańczuk, M., \& Zatoński, W. A. (2011). Depressive episodes and depressive tendencies among a sample of adults in Kielce, south-eastern Poland. Annals of Agricultural and Environmental Medicine, 18, 273-278.

Archer, T., Oscar-Berman, M., Blum, K., \& Gold, M. S. (2013). Epigenetic modulation of mood disorders. Journal of Genetic Syndromes \& Gene Therapy, 4, 1-13. https://doi.org/10.4172/2157-7412.1000120

Armitage, C. J. (2016). A brief psychological intervention to protect subjective well-being in a community sample. Quality of Life Research, 25, 385-391. https://doi.org/10.1007/s11136-015-1076-6

Armitage, C. J., Harris, P. R., \& Arden, M. A. (2011). Evidence that self-affirmation reduces alcohol consumption: Randomized exploratory trial with a new, brief means of self-affirming. Health Psychology, 30, 633-641. https://doi.org/10.1037/a0023738
Armitage, C. J., \& Rowe, R. (2011). Testing multiple means of self-affirmation: Testing multiple means of self-affirmation. British Journal of Psychology, 102, 535-545. https://doi.org/10.1111/j.2044-8295. 2010.02014.x

Baumeister, R. F., \& Sommer, K. L. (1997). What do men want? Gender differences and two spheres of belongingness: Comment on Cross and Madson (1997). Psychological Bulletin, 122, 38-44. https:// doi.org/10.1037/0033-2909.122.1.38

Bishara, A. J., \& Hittner, J. B. (2017). Confidence intervals for correlations when data are not normal. Behavior Research Methods, 49, 294-309. https:// doi.org/10.3758/s13428-016-0702-8

Bleidorn, W., Arslan, R. C., Denissen, J. J. A., Rentfrow, P. J., Gebauer, J. E., Potter, J., \& Gosling, S. D. (2016). Age and gender differences in self-esteem: a cross-cultural window. Journal of Personality and Social Psychology, 111, 396-410. https://doi.org/ 10.1037/pspp0000078

Boehm, J. K., Lyubomirsky, S., \& Sheldon, K. M. (2011). A longitudinal experimental study comparing the effectiveness of happiness-enhancing strategies in Anglo Americans and Asian Americans. Cognition and Emotion, 25, 1263-1272. https://doi.org/ 10.1080/02699931.2010.541227

Burd, K. A., \& Burrow, A. L. (2017). Conceptualizing similarities and differences between purpose in life and self-affirmation. Social and Personality Psychology Compass, 11, e12366. https://doi.org/10. 1111/spc3.12366

Burrow, A. L., \& Hill, P. L. (2011). Purpose as a form of identity capital for positive youth adjustment. Developmental Psychology, 47, 1196-1206. https:// doi.org/10.1037/a0023818

Burrow, A. L., \& Hill, P. L. (2013). Derailed by diversity? Purpose buffers the relationship between ethnic composition on trains and passenger negative mood. Personality and Social Psychology Bulletin, 39, 1610-1619. https://doi.org/ $10.1177 / 0146167213499377$

Cacioppo, J. T., \& Patrick, W. (2009). Loneliness: Human nature and the need for social connection. W. W. Norton.

Cassidy, S. A., Bradley, L., Bowen, E., Wigham, S., \& Rodgers, J. (2018). Measurement properties of tools used to assess depression in adults with and without autism spectrum conditions: a systematic review. Autism Research, 11, 738-754. https:// doi.org/10.1002/aur.1922

Cheng, W., Zhang, F., Liu, Z., Zhang, H., Lyu, Y., Xu, H., Hua, Y., Gu, J., Yang, Z., \& Liu, J. (2020). A psychological health support scheme for medical teams in COVID-19 outbreak and its effectiveness. General Psychiatry, 33, e100288. https://doi. org/10.1136/gpsych-2020-100288

Cohen, G. L., \& Sherman, D. K. (2014). The psychology of change: Self-affirmation and social 
psychological intervention. Annual Review of Psychology, 65, 333-371. https://doi.org/10.1146/ annurev-psych-010213-115137

Cohen, G. L., Purdie-Vaughns, V., \& Garcia, J. (2012). An identity threat perspective on intervention. In M. Inzlicht \& T. Schmader (Eds.), Stereotype threat: Theory, process, and application (pp. 280296). Oxford University Press.

Cohen, J. (1988). Statistical power analysis for the behavioral sciences (2nd ed). L. Erlbaum Associates.

Cohen, J. (1992). Statistical power analysis. Current Directions in Psychological Science, 1, 98-101. https://doi.org/10.1111/1467-8721.ep10768783

Cook, J. E., Purdie-Vaughns, V., Garcia, J., \& Cohen, G. L. (2012). Chronic threat and contingent belonging: Protective benefits of values affirmation on identity development. Journal of Personality and Social Psychology, 102, 479-496. https://doi. org/10.1037/a0026312

Cooke, R., Trebaczyk, H., Harris, P., \& Wright, A. J. (2014). Self-affirmation promotes physical activity. Journal of Sport \& Exercise Psychology, 36, 217-223. https://doi.org/10.1123/jsep.2013-0041

Critcher, C. R., \& Dunning, D. (2015). Self-affirmations provide a broader perspective on self-threat. Personality and Social Psychology Bulletin, 41, 3-18. https://doi.org/10.1177/0146167214554956

Crocker, J., Niiya, Y., \& Mischkowski, D. (2008). Why does writing about important values reduce defensiveness? Self-affirmation and the role of positive other-directed feelings. Psychological Science, 19, 740-747. https://doi.org/10.1111/j.14679280.2008.02150.x

Cross, S. E., \& Madson, L. (1997). Models of the self: Self-construals and gender. Psychological Bulletin, 122, 5-37. https://doi.org/10.1037/0033-2909.122.1.5

Damon, W., Menon, J., \& Cotton Bronk, K. (2003). The development of purpose during adolescence. Applied Developmental Science, 7, 119-128. https:// doi.org/10.1207/S1532480XADS0703_2

Diener, E., Suh, E. M., Lucas, R. E., \& Smith, H. L. (1999). Subjective well-being: Three decades of progress. Psychological Bulletin, 125, 276-302. https://doi.org/10.1037/0033-2909.125.2.276

Epton, T., \& Harris, P. R. (2008). Self-affirmation promotes health behavior change. Health Psychology, 27, 746-752. https://doi.org/10.1037/0278-6133.27. 6.746

Epton, T., Harris, P. R., Kane, R., van Koningsbruggen, G. M., \& Sheeran, P. (2015). The impact of self-affirmation on health-behavior change: a meta-analysis. Health Psychology, 34, 187-196. https://doi.org/10.1037/hea0000116

Faul, F., Erdfelder, E., Lang, A. G., \& Buchner, A. (2007). G*Power 3: a flexible statistical power analysis program for the social, behavioral, and biomedical sciences. Behavior Research Methods, 39, 175-191. https://doi.org/10.3758/BF03193146
Frankl, V. E., \& Vance, S. (2005). Man's search for meaning. Blackstone Audiobooks.

Gollwitzer, P. M., \& Sheeran, P. (2006). Implementation intentions and goal achievement: a metaanalysis of effects and processes. In M. P. Zanna (Ed.), Advances in experimental social psychology (Vol. 38, pp. 69-119). Elsevier.

Harackiewicz, J. M., Canning, E. A., Tibbetts, Y., Giffen, C. J., Blair, S. S., Rouse, D. I., \& Hyde, J. S. (2014). Closing the social class achievement gap for first-generation students in undergraduate biology. Journal of Educational Psychology, 106, 375-389. https://doi.org/10.1037/a0034679

Harris, P. R., Griffin, D. W., Napper, L. E., Bond, R., Schüz, B., Stride, C., \& Brearley, I. (2019). Individual differences in self-affirmation: Distinguishing self-affirmation from positive self-regard. Self and Identity, 18, 589-630. https://doi.org/10.1080/15298 868.2018.1504819

Hill, Z., Spiegel, M., \& Gennetian, L. A. (2020). Pride-based self-affirmations and parenting programs. Frontiers in Psychology, 11, 910. https://doi. org/10.3389/fpsyg.2020.00910

Howell, A. J. (2017). Self-affirmation theory and the science of well-being. Journal of Happiness Studies, 18, 293-311. https://doi.org/10.1007/s10902016-9713-5

Inglehart, R. (2002). Gender, aging, and subjective well-being. International Journal of Comparative Sociology, 43, 391-408. https://doi.org/ 10.1177/002071520204300309

Keough, K. A., \& Markus, H. R. (1998). The role of the self in building the bridge from philosophy to biology. Psychological Inquiry, 9, 49-53. https://doi. org/10.1207/s15327965pli0901_7

Keyes, C. L. M. (1998). Social well-being. Social Psychology Quarterly, 61, 121-140. https://doi.org/10. 2307/2787065

Keyes, C. L. M. (2005). Mental illness and/or mental health? Investigating axioms of the complete state model of health. Journal of Consulting and Clinical Psychology, 73, 539-548. https://doi. org/10.1037/0022-006X.73.3.539

Kleinman, A. M. (1977). Depression, somatization and the "new cross-cultural psychiatry." Social Science \& Medicine, 11, 3-9. https://doi.org/10.1016/00377856(77)90138-X

Koole, S. L., Smeets, K., van Knippenberg, A., \& Dijksterhuis, A. (1999). The cessation of rumination through self-affirmation. Journal of Personality and Social Psychology, 77, 111-125. https://doi. org/10.1037/0022-3514.77.1.111

Koole, S. L., \& van Knippenberg, A. (2007). Controlling your mind without ironic consequences: Self-affirmation eliminates rebound effects after thought suppression. Journal of Experimental Social Psychology, 43, 671-677. https://doi. org/10.1016/j.jesp.2006.07.001 
Layous, K., Katherine Nelson, S., \& Lyubomirsky, S. (2013). What is the optimal way to deliver a positive activity intervention? The case of writing about one's best possible selves. Journal of Happiness Studies, 14, 635-654. https://doi.org/10.1007/ s10902-012-9346-2

Lin, K. M., \& Cheung, F. (1999). Mental health issues for Asian Americans. Psychiatric Services, 50, 774780. https://doi.org/10.1176/ps.50.6.774

Logel, C., \& Cohen, G. L. (2012). The role of the self in physical health: Testing the effect of a valuesaffirmation intervention on weight loss. Psychological Science, 23, 53-55. https://doi.org/10. 1177/0956797611421936

Lyubomirsky, S., \& Layous, K. (2013). How do simple positive activities increase well-being? Current Directions in Psychological Science, 22, 57-62. https:// doi.org/10.1177/0963721412469809

Lyubomirsky, S., Sheldon, K. M., \& Schkade, D. (2005). Pursuing happiness: The architecture of sustainable change. Review of General Psychology, 9, 111131. https://doi.org/10.1037/1089-2680.9.2.111

Martela, F., \& Steger, M. F. (2016). The three meanings of meaning in life: Distinguishing coherence, purpose, and significance. The Journal of Positive Psychology, 11, 531-545. https://doi.org/10.1080/17 439760.2015.1137623

McKnight, P. E., \& Kashdan, T. B. (2009). Purpose in life as a system that creates and sustains health and well-being: an integrative, testable theory. Review of General Psychology, 13, 242-251. https:// doi.org/10.1037/a0017152

McQueen, A., \& Klein, W. M. P. (2006). Experimental manipulations of self-affirmation: a systematic review. Self and Identity, 5, 289-354. https://doi. org/10.1080/15298860600805325

Miyake, A., Kost-Smith, L. E., Finkelstein, N. D., Pollock, S. J., Cohen, G. L., \& Ito, T. A. (2010). Reducing the gender achievement gap in college science: a classroom study of values affirmation. Science, 330, 1234-1237. https://doi.org/10.1126/ science. 1195996

Munro, G. D., \& Stansbury, J. A. (2009). The dark side of self-affirmation: Confirmation bias and illusory correlation in response to threatening information. Personality and Social Psychology Bulletin, 35, 11431153. https://doi.org/10.1177/0146167209337163

Nelson, S. K., Fuller, J. A. K., Choi, I., \& Lyubomirsky, S. (2014). Beyond self-protection: Self-affirmation benefits hedonic and eudaimonic well-being. Personality and Social Psychology Bulletin, 40, 9981011. https://doi.org/10.1177/0146167214533389

Ogihara, Y. (2020). The pattern of age differences in self-esteem is similar between males and females in Japan: Gender differences in developmental trajectories of self-esteem from childhood to old age. Cogent Psychology, 7, 1756147. https://doi.org/ 10.1080/23311908.2020.1756147
Pandey, R. (2021). Exploring and assessing the restorative and prophylactic efficacy of self-affirmation for depressive tendencies [Doctoral thesis]. Doctor Harisingh Gour Vishwavidyalaya, Sagar, Madhya Pradesh, India.

Pandey, R., Tiwari, G. K., Parihar, P., \& Rai, P. K. (2021). Positive, not negative, self-compassion mediates the relationship between self-esteem and well-being. Psychology and Psychotherapy: Theory, Research and Practice, 94, 1-15. https://doi. org/10.1111/papt.12259

Pandey, R., Tiwari, G. K., Parihar, P., \& Rai, P. K. (2020a). The relationship between self-forgiveness and human flourishing: Inferring the underlying psychological mechanisms. Polish Psychological Bulletin, 51, 23-36. https://doi.org/10.24425/PPB.2020.132649

Pandey, R., Tiwari, G. K., \& Rai, P. K. (2020b). "Bouncing back" with self-affirmation intervention: a case of Indian adults with depressive tendencies. Madhya Bharti, 79, 252-263.

Russell, S. T., Pollitt, A. M., Li, G., \& Grossman, A. H. (2018). Chosen name use is linked to reduced depressive symptoms, suicidal ideation, and suicidal behavior among transgender youth. Journal of Adolescent Health, 63, 503-505. https://doi. org/10.1016/j.jadohealth.2018.02.003

Ryan, R. M., \& Deci, E. L. (2001). On happiness and human potentials: a review of research on hedonic and eudaimonic well-being. Annual Review of Psychology, 52, 141-166. https://doi.org/10.1146/ annurev.psych.52.1.141

Ryff, C. D. (1989). Happiness is everything, or is it? Explorations on the meaning of psychological well-being. Journal of Personality and Social Psychology, 57, 1069-1081. https://doi.org/ 10.1037/0022-3514.57.6.1069

Ryff, C. D., \& Keyes, C. L. M. (1995). The structure of psychological well-being revisited. Journal of Personality and Social Psychology, 69, 719-727. https://doi.org/10.1037/0022-3514.69.4.719

Schaefer, S. M., Morozink Boylan, J., van Reekum, C. M., Lapate, R. C., Norris, C. J., Ryff, C. D., \& Davidson, R. J. (2013). Purpose in life predicts better emotional recovery from negative stimuli. PLoS One, 8, e80329. https://doi.org/10.1371/journal.pone. 0080329

Scheier, M. F., Wrosch, C., Baum, A., Cohen, S., Martire, L. M., Matthews, K. A., Schulz, R., \& Zdaniuk, B. (2006). The life engagement test: Assessing purpose in life. Journal of Behavioral Medicine, 29, 291-298. https://doi.org/10.1007/s10865-005-9044-1

Schimel, J., Arndt, J., Banko, K. M., \& Cook, A. (2004). Not all self-affirmations were created equal: The cognitive and social benefits of affirming the intrinsic (vs. extrinsic) self. Social Cognition, 22, 7599. https://doi.org/10.1521/soco.22.1.75.30984

Schmeichel, B. J., \& Martens, A. (2005). Self-affirmation and mortality salience: Affirming values reduces 
worldview defence and death-thought accessibility. Personality and Social Psychology Bulletin, 31, 658-667. https://doi.org/10.1177/0146167204271567

Schmeichel, B. J., \& Vohs, K. (2009). Self-affirmation and self-control: Affirming core values counteracts ego depletion. Journal of Personality and Social Psychology, 96, 770-782. https://doi.org/10.1037/ a0014635

Sherman, D. K. (2013). Self-affirmation: Understanding the effects: self-affirmation: understanding the effects. Social and Personality Psychology Compass, 7, 834-845. https://doi.org/10.1111/spc3.12072

Sherman, D. K., \& Cohen, G. L. (2002). Accepting threatening information: Self-affirmation and the reduction of defensive biases. Current Directions in Psychological Science, 11, 119-123. https://doi. org/10.1111/1467-8721.00182

Shnabel, N., Purdie-Vaughns, V., Cook, J. E., Garcia, J., \& Cohen, G. L. (2013). Demystifying values-affirmation interventions: Writing about social belonging is a key to buffering against identity threat. Personality and Social Psychology Bulletin, 39, 663676. https://doi.org/10.1177/0146167213480816

Sin, N. L., \& Lyubomirsky, S. (2009). Enhancing wellbeing and alleviating depressive symptoms with positive psychology interventions: a practicefriendly meta-analysis. Journal of Clinical Psychology, 65, 467-487. https://doi.org/10.1002/jclp.20593

Smith, P. B., Easterbrook, M. J., al-Selim, H., Lun, V. M. C., Koc, Y., Gul, P., Papastylianou, D., Grigoryan, L., Torres, C., Efremova, M., Hassan, B., Ahmad, A. H., al-Bayati, A., Anderson, J., Cross, S. E., Delfino, G. I., Gamsakhurdia, V., Gavreliuc, A., Gavreliuc, D., ... Chobthamkit, P. (2020). Sex differences in self-construal and in depressive symptoms: Predictors of cross-national variation. Journal of Cross-Cultural Psychology, 51, 616-635. https://doi.org/10.1177/0022022120939655

Spencer, S. J., Josephs, R. A., \& Steele, C. M. (1993). Low self-esteem: The uphill struggle for self-integrity. In R. F. Baumeister (Ed.), Self-esteem: The puzzle of low self-regard (pp. 21-36). Plenum Press.

Spencer-Rodgers, J., Major, B., Forster, D. E., \& Peng, K. (2016). The power of affirming group values: Group affirmation buffers the self-esteem of women exposed to blatant sexism. Self and Identity, 15, 413431. https://doi.org/10.1080/15298868.2016.1145593

Sprecher, S., Brooks, J. E., \& Avogo, W. (2013). Selfesteem among young adults: Differences and similarities based on gender, race, and cohort (19902012). Sex Roles, 69, 264-275. https://doi.org/10. 1007/s11199-013-0295-y

Steele, C. M. (1988). The psychology of self-affirmation: Sustaining the integrity of the self. In L. Berkowitz (Ed.), Advances in experimental social psychology (pp. 261-302). Academic Press.

Steele, C. M., Spencer, S. J., \& Lynch, M. (1993). Selfimage resilience and dissonance: The role of af- firmational resources. Journal of Personality and Social Psychology, 64, 885-896. https://doi.org/ 10.1037//0022-3514.64.6.885

Sumner, R., Burrow, A. L., \& Hill, P. L. (2015). Identity and purpose as predictors of subjective well-being in emerging adulthood. Emerging Adulthood, 3, 46-54. https://doi.org/10.1177/2167696814532796

Sweeney, A. M., \& Moyer, A. (2015). Self-affirmation and responses to health messages: a meta-analysis on intentions and behavior. Health Psychology, 34, 149-159. https://doi.org/10.1037/hea0000110

Taylor, S. E., \& Brown, J. D. (1988). Illusion and wellbeing: a social psychological perspective on mental health. Psychological Bulletin, 103, 193-210.

Thomaes, S., Bushman, B. J., de Castro, B. O., \& Reijntjes, A. (2012). Arousing "gentle passions" in young adolescents: Sustained experimental effects of value affirmations on prosocial feelings and behaviors. Developmental Psychology, 48, 103-110. https://doi.org/10.1037/a0025677

Tiwari, G. K., Kashyap, A. K., Rai, P. K., Tiwari, R. P., \& Pandey, R. (2020a). The collective-affirmation in action: Understanding the success of lockdown in India after the outbreak of COVID-19 [preprint]. Authorea. https://doi.org/10.22541/au. 158949202.27402247

Tiwari, G. K., Tiwari, R. P., Pandey, R., Ray, B., Dwivedi, A., Sharma, D. N., Singh, P., \& Tiwari, A. K. (2020b). The life outcomes of children during COVID-19: Exploring the protective roles of the joint and nuclear families in India [preprint]. Authorea. https://doi.org/10.22541/au.159769493.33057412

Ugwu, I. D., Amico, F., Carballedo, A., Fagan, A. J., \& Frodl, T. (2015). Childhood adversity, depression, age and gender effects on white matter microstructure: a DTI study. Brain Structure and Function, 220, 1997-2009. https://doi.org/10.1007/ s00429-014-0769-x

Walton, G. M., \& Cohen, G. L. (2011). A brief socialbelonging intervention improves academic and health outcomes of minority students. Science, 331, 1447-1451. https://doi.org/10.1126/science.1198364

Wright, D. B., London, K., \& Field, A. P. (2011). Using bootstrap estimation and the plug-in principle for clinical psychology data. Journal of Experimental Psychopathology, 2, 252-270. https://doi. org/10.5127/jep.013611

Yildirim, T. T., Dundar, S., Bozoglan, A., Karaman, T., Dildes, N., Acun Kaya, F., Altintas, E., Oztekin, F., Atas, O., \& Alan, H. (2017). Is there a relation between dental anxiety, fear and general psychological status? PeerJ, 5, e2978. https://doi.org/10.7717/ peerj.2978

Zhu, L. (2018). Depression symptom patterns and social correlates among Chinese Americans. Brain Sciences, 8, 16. https://doi.org/10.3390/brainsci8010016 